\title{
STUDIES OF TYLOSIN DERIVATIVES EFFECTIVE AGAINST MACROLIDE-RESISTANT STRAINS: SYNTHESIS AND STRUCTURE-ACTIVITY RELATIONSHIPS
}

\author{
Masami Tsuchiya, Masa Hamada, Tomio Takeuchi \\ and HAMAO UMEZAWA \\ Institute of Microbial Chemistry \\ 14-23 Kamiosaki 3-Chome, Shinagawa-ku, Tokyo \\ Kenichi Yamamoto, Hiroshi TanaKa, Kohki Kiyoshima, \\ SHUNRo MORI and ROKuro OKamoto \\ Central Research Laboratories, Sanraku-Ocean Co., Ltd. \\ 9-1, Johnan 4-Chome, Fujisawa, Kanagawa, Japan
}

(Received for publication December 26, 1981)

\begin{abstract}
The $4^{\prime \prime}-O$-substituted tylosin derivatives were prepared by selective esterification of the $4^{\prime \prime}-\mathrm{OH}$, and relationships between the substituent groups and antimicrobial activity against macrolide-resistant strains were examined. Introduction of branched-chain aliphatic acyl groups such as 2-methoxyisovaleryl or 4-methylvaleryl group afforded derivatives with good antibacterial activity; MIC values were $12.5 \mu \mathrm{g} / \mathrm{ml}$ against Staphylococcus aureus MS-8710. MIC values of tylosin, erythromycin and josamycin against this strain were $800 \mu \mathrm{g} / \mathrm{ml}$ or more. Further improved activity was obtained by introduction of aromatic groups such as phenylthioacetyl, phenylsulfonylacetyl, 4-nitrophenylacetyl, 4-nitrophenylsulfonyl and phenylethanesulfonyl groups; MIC values were $6.25 \mu \mathrm{g} / \mathrm{ml}$. These derivatives had also an improved antimycoplasmal activity; MIC values were $0.08 \mu \mathrm{g} / \mathrm{ml}$ against macrolide-resistant strains of Mycoplasma gallisepticum. MIC values of tylosin against these strains were from 2.5 to $10 \mu \mathrm{g} /$ $\mathrm{ml}$. Introduction of the groups described above into the $4^{\prime \prime}-\mathrm{OH}$ was confirmed to increase the uptake by a resistant strain.
\end{abstract}

In our previous paper ${ }^{1)}$, the relative significance of the 3-, 2'-, 4' - and 4"' -O-acyl groups of tylosin on antibacterial activity against Staphylococcus aureus was reported. Acylation of the 4"-hydroxyl group of tylosin resulted in an improved antibacterial activity against macrolide-resistant strains, while acylation of the 2'- and/or 4"'-hydroxyl group(s) of tylosin produced a negative effect. The antibacterial activity of tylosin was not or little affected by the C-3 acylation. Moreover, acylation of the 4 "'-hydroxyl group also provided derivatives which produced a higher blood level in mice and rabbits than tylosin and a good therapeutic effect against infection after oral administration ${ }^{1)}$. From the study of the action of 3-O-acetyl-4" $-O$-isovaleryltylosin against a macrolide-resistant strain of $S$. aureus, it became clear that the introduction of an isovaleryl group onto the $4^{\prime \prime}$-hydroxyl group enhances both penetration into the bacterial cells and the binding ability to ribosomes ${ }^{2,3)}$.

The mycinose moiety attached to the $23-\mathrm{OH}$ of aglycone was also shown to have an important role in the antibacterial activity against macrolide-resistant strains ${ }^{3)}$. Therefore, we synthesized a large number of tylosin derivatives by introducing a variety of groups into the C-4" hydroxyl group, with the aim to obtain derivatives having improved therapeutic activity against infection of macrolide-resistant isolates. 
In this paper, we describe the preparation of new tylosin derivatives, and relationships between the structures of the $4^{\prime \prime}$ - $O$-substituent groups and their antibacterial effects.

Chemical Synthesis of New Tylosin Derivatives (Table 1)

Table 1. Tylosin derivatives synthesized, methods for synthesis, physicochemical properties and their antibacterial activity against a tylosin-resistant strain MS-8710.

\begin{tabular}{|c|c|c|c|c|c|c|}
\hline \multicolumn{2}{|r|}{ Compound } & \multirow{2}{*}{$\begin{array}{c}\text { Structure of } \\
\text { substituent group } \\
\text { at } 4^{\prime \prime}-O-\end{array}$} & \multirow{2}{*}{$\begin{array}{c}\text { Method } \\
\text { for } \\
\text { synthesis }^{*} 1\end{array}$} & \multirow{2}{*}{$\begin{array}{l}\text { Melting } \\
\text { point } \\
\left({ }^{\circ} \mathrm{C}\right)\end{array}$} & \multirow{2}{*}[\alpha]{$_{\mathrm{D}}^{22 * 2}$} & \multirow{2}{*}{$\begin{array}{c}\mathrm{MIC} \\
(\mu \mathrm{g} / \mathrm{ml}) \\
\mathrm{MS}-8710\end{array}$} \\
\hline No. & Name & & & & & \\
\hline 1 & Tylosin (parent compound) & $\mathrm{H}$ & & & & 800 \\
\hline 2 & $2^{\prime}$-O-Acetyltylosin & $\mathrm{H}$ & $\mathrm{b}$ & $123 \sim 127$ & -74.8 & $>200$ \\
\hline 3 & $\begin{array}{l}2^{\prime}-O-\text { Acetyl-4" }{ }^{\prime \prime \prime}-O- \\
\text { monochloroacetyltylosin }\end{array}$ & $\mathrm{H}$ & $\mathrm{b}$ & $127 \sim 132$ & -25.6 & $>200$ \\
\hline 4 & $\begin{array}{l}\text { 2'-O-Acetyl-4"' }-O- \\
\text { trichloroacetyltylosin }\end{array}$ & $\mathrm{H}$ & $b$ & $129 \sim 132$ & -46.4 & $>200$ \\
\hline 5 & $3,2^{\prime}$-Di- $O$-acetyltylosin & $\mathrm{H}$ & $\mathrm{a}$ & $117 \sim 119$ & -41.4 & $>200$ \\
\hline 6 & $\begin{array}{l}3,2^{\prime}-\mathrm{Di}-O \text {-acetyl- } 4^{\prime \prime \prime}-O- \\
\text { monochloroacetyltylosin }\end{array}$ & $\mathrm{H}$ & b & $111 \sim 113$ & -35.8 & $>200$ \\
\hline 7 & $\begin{array}{l}\text { 3,2'-Di- } O \text {-acetyl-4"' }-O- \\
\text { trichloroacetyltylosin }\end{array}$ & $\mathrm{H}$ & b & $116 \sim 120$ & -20.0 & $>200$ \\
\hline 8 & $4^{\prime \prime}-O$-Acetyltylosin & $\mathrm{CO}-\mathrm{CH}_{3}$ & b & $124 \sim 127$ & -54.2 & 100 \\
\hline 9 & $4^{\prime \prime}-O$-Butyryltylosin & $\mathrm{CO}-\mathrm{CH}_{2}-\mathrm{CH}_{2}-\mathrm{CH}_{3}$ & $\mathrm{~m}$ & $147 \sim 151$ & -53.4 & 25 \\
\hline 10 & $4^{\prime \prime}-O$-Isovaleryltylosin & $\mathrm{CO}-\mathrm{CH}_{2}-\mathrm{CH}\left(\mathrm{CH}_{3}\right)_{2}$ & $\mathrm{~m}$ & $154 \sim 156$ & -50.8 & 25 \\
\hline 11 & $4^{\prime \prime}-O-(2-M e t h o x y)$ isovaleryltylosin & $\begin{array}{l}\mathrm{CO}-\mathrm{CH}\left(\mathrm{OCH}_{3}\right)- \\
\mathrm{CH}\left(\mathrm{CH}_{3}\right)_{2}\end{array}$ & b & $130 \sim 135$ & -45.7 & 12.5 \\
\hline 12 & $4^{\prime \prime}-O$-(4-Methyl)valeryltylosin & $\begin{array}{l}\mathrm{CO}-\mathrm{CH}_{2}-\mathrm{CH}_{2}- \\
\mathrm{CH}\left(\mathrm{CH}_{3}\right)_{2}\end{array}$ & a & $209 \sim 214$ & -50.7 & 12.5 \\
\hline 13 & $4^{\prime \prime}-O-(2-M e t h y l) v a l e r y l t y l o s i n$ & $\begin{array}{c}\mathrm{CO}-\mathrm{CH}\left(\mathrm{CH}_{3}\right)-\mathrm{CH}_{2}- \\
\mathrm{CH}_{2}-\mathrm{CH}_{3}\end{array}$ & b & $100 \sim 104$ & -31.2 & 25 \\
\hline 14 & $4^{\prime \prime}-O$-Hexanoyltylosin & $\mathrm{CO}-\left(\mathrm{CH}_{2}\right)_{4}-\mathrm{CH}_{3}$ & a & $105 \sim 109$ & -59.0 & 25 \\
\hline 15 & 4"-O-Octanoyltylosin & $\mathrm{CO}-\left(\mathrm{CH}_{2}\right)_{8}-\mathrm{CH}_{3}$ & a & $90 \sim 94$ & -48.8 & 25 \\
\hline 16 & 4"-O-Decanoyltylosin & $\mathrm{CO}-\mathrm{CH}$ & a & $85 \sim 90$ & -68.6 & $>200$ \\
\hline 17 & 4"-O-Benzoyltylosin & & $\mathrm{b}$ & $129 \sim 134$ & -32.6 & 100 \\
\hline 18 & $4^{\prime \prime}-O-(2-F u r o y l) t y l o s i n$ & & $\mathrm{~b}$ & $129 \sim 133$ & -47.8 & 100 \\
\hline 19 & 4"'-O-Phenylacetyltylosin & & b & $104 \sim 109$ & -56.1 & 50 \\
\hline 20 & $4^{\prime \prime}-O-(4-N i t r o p h e n y l a c e t y l) t y l o s i n$ & & $\mathrm{~b}$ & $115 \sim 126$ & -46.1 & 6.25 \\
\hline 21 & $4^{\prime \prime}-O-(\alpha-N a p h t h y l) a c e t y l t y l o s i n$ & & $\mathrm{~b}$ & $118 \sim 121$ & -49.6 & 12.5 \\
\hline 22 & $4^{\prime \prime}-O-(2-T h i e n y 1)$ acetyltylosin & & $\mathrm{b}$ & $115 \sim 118$ & -32.4 & 12.5 \\
\hline 23 & $4^{\prime \prime}-O$-(3-Phenylpropionyl)tylosin & & $\mathrm{b}$ & $110 \sim 112$ & -58.6 & 12.5 \\
\hline 24 & $\begin{array}{l}4^{\prime \prime}-O-(3-C y c l o h e x y l p r o p i o n y l)- \\
\text { tylosin }\end{array}$ & & a & $102 \sim 106.5$ & -46.8 & 25 \\
\hline 25 & $4^{\prime \prime}-O$-(Phenoxy)acetyltylosin & $\mathrm{CO}-$ & $\mathrm{b}$ & $115 \sim 117$ & -50.6 & 25 \\
\hline 26 & $4 " \prime-O-(\beta-N a p h t h o x y)$ acetyltylosin & & $\mathrm{b}$ & $122 \sim 127$ & -43.0 & 25 \\
\hline 27 & 4"-O-(Phenylsulfonyl)acetyltylosin & & $b$ & $110 \sim 116$ & -41.0 & 6.25 \\
\hline 28 & 4"-O-(Phenylthio)acetyltylosin & 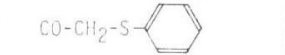 & $\mathrm{b}$ & $105 \sim 107$ & -49.8 & 6.25 \\
\hline
\end{tabular}


Table 1. (continued)

\begin{tabular}{|c|c|c|c|c|c|c|}
\hline \multicolumn{2}{|r|}{ Compound } & \multirow{2}{*}{$\begin{array}{c}\text { Structure of } \\
\text { substituent group } \\
\text { at } 4^{\prime \prime}-O-\end{array}$} & \multirow{2}{*}{\begin{tabular}{c|} 
Method \\
for \\
synthesis*1
\end{tabular}} & \multirow{2}{*}{$\begin{array}{l}\text { Melting } \\
\text { point } \\
\left({ }^{\circ} \mathrm{C}\right)\end{array}$} & \multirow{2}{*}[\alpha]{$_{\mathrm{D}}^{2 * 2}$} & \multirow{2}{*}{$\begin{array}{c}\mathrm{MIC} \\
(\mu \mathrm{g} / \mathrm{ml}) \\
\mathrm{MS}-8710\end{array}$} \\
\hline No. & Name & & & & & \\
\hline 29 & $4^{\prime \prime}-O$-(Cyclohexylthio)acetyltylosin & & $\mathrm{c}$ & $112 \sim 116$ & -37.2 & 12.5 \\
\hline 30 & $4^{\prime \prime}-O$-(4-Pyridylthio)acetyltylosin & & $\mathrm{c}$ & $116 \sim 118$ & -54.2 & 12.5 \\
\hline 31 & $\begin{array}{l}\text { 4"-O-(4-Methylphenylthio)- } \\
\text { acetyltylosin }\end{array}$ & & $b$ & $112 \sim 114$ & -48.9 & 25 \\
\hline 32 & $\begin{array}{l}\text { 4'-O-(4-Chlorophenylthio)- } \\
\text { acetyltylosin }\end{array}$ & & c & $109 \sim 113$ & -43.8 & 12.5 \\
\hline 33 & $\begin{array}{l}4^{\prime \prime}-O \text {-(Pentachlorophenylthio)- } \\
\text { acetyltylosin }\end{array}$ & & $\mathrm{b}$ & $106 \sim 110$ & -38.6 & $>200$ \\
\hline 34 & $\begin{array}{l}4^{\prime \prime}-O-(3-\text { Phenylthio)- } \\
\text { propionyltylosin }\end{array}$ & & $\mathrm{b}$ & $103 \sim 107.5$ & -40.8 & 12.5 \\
\hline 35 & $\begin{array}{l}\text { 3-O-Acetyl-4"-O-(3-pyridyl)- } \\
\text { acetyltylosin }\end{array}$ & & $\mathrm{c}$ & $109 \sim 112$ & -28.4 & 12.5 \\
\hline 36 & $\begin{array}{l}\text { 3-O-Acetyl-4"-O-(dimethylamino)- } \\
\text { acetyltylosin }\end{array}$ & $\mathrm{CO}-$ & b & $96 \sim 103$ & -32.0 & $>200$ \\
\hline 37 & $\begin{array}{l}\text { 3-O-Acetyl-4"'-O-(morpholino)- } \\
\text { acetyltylosin }\end{array}$ & & $\mathrm{c}$ & $114 \sim 117$ & -26.8 & 50 \\
\hline 38 & $\begin{array}{l}\text { 3-O-Acetyl-4"'-O-(4-methyl- } \\
\text { piperazinoacetyl)tylosin }\end{array}$ & & $\mathrm{c}$ & $110 \sim 114$ & -29.6 & 100 \\
\hline 39 & $\begin{array}{l}\text { 3-O-Acetyl-4" }-O \text { - }(1 \text {-imidazolyl- } \\
\text { propionyl)tylosin }\end{array}$ & & $\mathrm{c}$ & $110 \sim 115$ & -29.6 & 25 \\
\hline 40 & $\begin{array}{l}\text { 3-O-Acetyl-4"'-O-(1-triazolyl- } \\
\text { propionyl)tylosin }\end{array}$ & & $\mathrm{c}$ & $108 \sim 112$ & -31.4 & $>200$ \\
\hline 41 & $\begin{array}{l}\text { 3-O-Acetyl-4" }-O \text {-(1,2-dithiolane-3- } \\
\text { valeryl)tylosin }\end{array}$ & & b & $77 \sim 82$ & -25.4 & 25 \\
\hline 42 & $\begin{array}{l}\text { 3-O-Acetyl-4" }-O-\mathrm{D}-(2- \\
\text { hydroxyphenylacetyl)tylosin }\end{array}$ & & b & $115 \sim 118$ & -23.0 & 12.5 \\
\hline 43 & $\begin{array}{l}\text { 3-O-Acetyl-4" }-O-\mathrm{D}-(2- \\
\text { acetoxyphenylacetyl)tylosin }\end{array}$ & & b & $111 \sim 114$ & -53.8 & 100 \\
\hline 44 & $\begin{array}{l}4^{\prime \prime}-O-(\alpha-N a p h t h a l e n e s u l f o n y l)- \\
\text { tylosin }\end{array}$ & & b & $127 \sim 139$ & -43.4 & $>200$ \\
\hline 45 & 4"'-O-Phenylsulfonyltylosin & & $\mathrm{b}$ & $121 \sim 128$ & -42.4 & 12.5 \\
\hline 46 & $\begin{array}{l}\text { 4"-O-(4-Nitrophenylsulfonyl)- } \\
\text { tylosin }\end{array}$ & & b & $124 \sim 129$ & -44.8 & 6.25 \\
\hline 47 & $4^{\prime \prime}-O$-Phenylmethanesulfonyltylosin & & $\mathrm{b}$ & $117 \sim 121$ & -24.4 & 12.5 \\
\hline 48 & $4^{\prime \prime}$-O-Phenylethanesulfonyltylosin & so & $\mathrm{b}$ & $115 \sim 121$ & -35.6 & 6.25 \\
\hline 49 & $\begin{array}{l}4^{\prime \prime}-O \text {-Phenylthioethanesulfonyl- } \\
\text { tylosin }\end{array}$ & & b & $94 \sim 98$ & -37.4 & 12.5 \\
\hline
\end{tabular}

*1 Methods for esterification at the 4"-OH, described in the experimental part.

a; General Method a, b; General Method b, c; General Method c, m; microbial transformation.

*2 $c 0.5, \mathrm{MeOH}$

As shown in Fig. 1, tylosin (1), a 16-membered macrolide antibiotic, has four secondary hydroxyl groups (C-3, C-2', C-4" and C-4'"') and a tertiary hydroxyl group (C-3'). The latter is far less reactive than the former groups. In order to modify selectively the 4 "'-OH, the residual secondary hydroxyl groups were successfully protected with suitable blocking agents.

Selective acetylation of the $2^{\prime}-\mathrm{OH}$ was successful by treatment of 1 in acetone with acetyl chloride in the presence of potassium hydrogen carbonate, giving $2^{\prime}$-O-acetyltylosin (2) as reported previously ${ }^{6)}$. The location of this acetyl group was confirmed by ${ }^{1} \mathrm{H}$ NMR and mass spectrum. 
Fig. 1. Intermediates for synthesis of tylosin derivatives and protective groups.

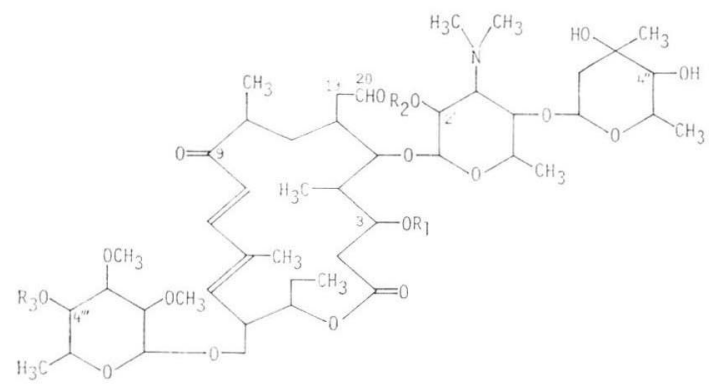

\begin{tabular}{c|ccc}
\hline Compound & $\mathrm{R}_{1}$ & $\mathrm{R}_{2}$ & $\mathrm{R}_{3}$ \\
\hline $\mathbf{1}$ & $\mathrm{H}$ & $\mathrm{H}$ & $\mathrm{H}$ \\
$\mathbf{2}$ & $\mathrm{H}$ & $\mathrm{COCH}_{3}$ & $\mathrm{H}$ \\
$\mathbf{3}$ & $\mathrm{H}$ & $\mathrm{COCH}_{3}$ & $\mathrm{COCH}_{2} \mathrm{Cl}$ \\
$\mathbf{4}$ & $\mathrm{H}$ & $\mathrm{COCH}_{3}$ & $\mathrm{COCCl}_{3}$ \\
$\mathbf{5}$ & $\mathrm{COCH}_{3}$ & $\mathrm{COCH}_{3}$ & $\mathrm{H}$ \\
$\mathbf{6}$ & $\mathrm{COCH}_{3}$ & $\mathrm{COCH}_{3}$ & $\mathrm{COCH}_{2} \mathrm{Cl}$ \\
$\mathbf{7}$ & $\mathrm{COCH}_{3}$ & $\mathrm{COCH}_{3}$ & $\mathrm{COCCl}_{3}$ \\
\hline
\end{tabular}

The reactivities of other secondary hydroxyl groups were examined and the 4"'-OH was found to be the most reactive. Reaction of 2 in methylene chloride $\left(\mathrm{CH}_{2} \mathrm{Cl}_{2}\right)$ with chloroacetyl chloride $\left(\mathrm{ClCH}_{2}-\right.$ $\mathrm{COCl})$ or trichloroacetyl chloride $\left(\mathrm{CCl}_{3} \mathrm{COCl}\right)$ in the presence of pyridine $\left(-15^{\circ} \mathrm{C}, 5\right.$ minutes $)$ gave $2^{\prime}-$ $O$-acetyl-4" "- $O$-monochloroacetyltylosin (3) or 2'-O-acetyl-4"' $O$-trichloroacetyltylosin (4).

Modification of the $4^{\prime \prime}-\mathrm{OH}$ of $\mathbf{3}$ or $\mathbf{4}$ performed according to the method reported for synthesis of derivatives of deltamycin ${ }^{4)}$ etc. gave mainly $4^{\prime \prime}$ - $O$-substituted-2',4"'-O-protected derivatives. In the reactions, 3,4"-di- $O$-substituted-2',4"' - $O$-protected derivatives were obtained as a minor product: the yield was dependent on reaction conditions and reagents used for esterification. Removal of the 2'and 4 "' $-O$-protective groups selectively was successful by refluxing in $95 \%$ methanol, yielding $4{ }^{\prime \prime}-O$ substituted tylosin derivatives. 3-O-Acetyl-4"'-O-substituted derivatives were also chemically synthesized by the same method starting from 3-O-acetyltylosin ${ }^{5)}$ instead of $\mathbf{1}$. Synthesis of intermediate compounds (Fig. 1) and new tylosin derivatives is described in detail in experimental section. Physicochemical properties of new tylosin derivatives reported are shown in Table 1 together with their antibacterial activity against a macrolide-resistant strain MS-8710 of S. aureus.

\section{Structure-Activity Relationships}

1. Antibacterial Activity against Macrolide-resistant Strains of Staphylococcus aureus

To examine the effect of aliphatic acyl groups introduced onto the 4"-hydroxyl group on the antibacterial activity, we prepared tylosin derivatives having straight and branched-chain aliphatic acyl groups on the 4"-OH from two to ten carbon atoms. Their MIC values against Staphylococcus aureus MS-8710 are shown in Table 1 (compounds $8 \sim 16$ in Table). The derivatives having from four to eight carbon atoms in the straight-chain acyl groups showed the same degree of antibacterial activity. 4 " $O$-Decanoyltylosin had the decreased antibacterial activity. The stronger activity against resistant strains was shown by 4 "'-O-(2-methoxy)isovaleryltylosin and 4 "'-O-(4-methyl)valeryltylosin: MIC values of both compounds were $12.5 \mu \mathrm{g} / \mathrm{ml}$. For comparison, the strain MS-8710 was resistant to 800 $\mu \mathrm{g} / \mathrm{ml}$ of erythromycin, leukomycin, josamycin, spiramycin, tylosin and angolamycin.

We prepared tylosin 4 "- $O$-derivatives containing aromatic, alicyclic and heterocyclic groups and tested their antibacterial activity against resistant strains. Structures of substituent groups and MIC values of the derivatives are shown in Table 1 (compounds 17 43 in Table). The activity was elevated in the increasing order of 4"-O-benzoyl (17), phenylacetyl (19) and (3-phenylpropionyl) (23) tylosins. 4"-O-(Phenylthio)acetyl (28) and (phenylsulfonyl)acetyl (27) tylosins showed a further stronger activity; MIC values of both compounds were $6.25 \mu \mathrm{g} / \mathrm{ml}$. The substitution of a hydrogen atom with methyl group (31) or chlorine group $(\mathbf{3 2}, \mathbf{3 3})$ in the phenyl moiety of these derivatives caused a decrease of the 
Table 2. The activity in inhibiting mycoplasma resistant to macrolides and the 4 "'-O-substituents.

\begin{tabular}{|c|c|c|c|c|c|c|}
\hline \multirow{2}{*}{ Compound } & \multirow{2}{*}{$\begin{array}{l}\text { Substituent } \\
\text { group at } \\
\text { the } 4^{\prime \prime}-O \text { - }\end{array}$} & \multicolumn{5}{|c|}{ Mycoplasma gallisepticum: MIC ( $\mu \mathrm{g} / \mathrm{ml})$} \\
\hline & & E-5 & E-11 & A-68 & A-72 & KP-13 \\
\hline Erythromycin & & 100 & 100 & 100 & 100 & 0.1 \\
\hline Spiramycin & & 100 & 100 & 100 & 100 & 0.1 \\
\hline Tylosin & $\mathrm{H}$ & 10 & 5 & 2.5 & 2.5 & 0.02 \\
\hline Mycaminosyl tylonolide* & & $>10$ & $>10$ & $>10$ & $>10$ & 0.16 \\
\hline $\begin{array}{l}\text { 3-O-Acetyl-4"'-O-isovaleryl demycinosyl } \\
\text { tylosin* }\end{array}$ & $\mathrm{CO}-\mathrm{CH}_{2}-\mathrm{CH}\left(\mathrm{CH}_{3}\right)_{2}$ & 10 & 2.5 & 2.5 & 1.25 & 0.02 \\
\hline 3-O-Acetyl-4"'-O-isovaleryltylosin & $\mathrm{CO}-\mathrm{CH}_{2}-\mathrm{CH}\left(\mathrm{CH}_{3}\right)_{2}$ & 0.62 & 0.31 & 0.31 & 0.31 & 0.02 \\
\hline $4^{\prime \prime}-O$-(Phenylthio)acetyltylosin & & 0.08 & 0.08 & 0.08 & 0.08 & 0.04 \\
\hline $4{ }^{\prime \prime}-O$-(4-Nitrophenylacetyl)tylosin & C & 0.08 & 0.08 & 0.08 & 0.08 & 0.04 \\
\hline 4"'-O-(Phenylsulfonyl)acetyltylosin & C & 0.08 & 0.08 & 0.08 & 0.08 & 0.04 \\
\hline Chloramphenicol & & 10 & 3 & 30 & 10 & 30 \\
\hline Tetracycline & & 1 & 0.3 & 1 & 1 & 1 \\
\hline
\end{tabular}

* Chemical structures were reported in previous papers. ${ }^{3)}$

antibacterial activity. This was clearly shown in $4^{\prime \prime}-O$-(phenylthio)acetyltylosin derivatives. The replacement of the benzene group of the derivatives with cyclohexane (29) and pyridine (30) did not increase the activity. The introduction of the groups having the other heterocyclic structures and the different length of methylene-chain (compounds $35 \sim 43$ in Table) did not afford a further increased activity. However, $4^{\prime \prime}-O$-(4-nitrophenylacetyl)tylosin (20) showed the same degree of antibacterial activity as $4^{\prime \prime}$ - $O$-(phenylthio)acetyltylosin. We prepared also $4^{\prime \prime}$ - $O$-sulfonyl derivatives as shown in Table 1 (compounds $44 \sim 49$ in Table). The length of the carbon chain in this case did not show any effect on the activity. Among 4"'-O-sulfonyl derivatives, 4"-O-phenylethanesulfonyltylosin (48) and 4"-O-(4nitrophenylsulfonyl)tylosin (46) showed a strong antibacterial activity (MIC, $6.25 \mu \mathrm{g} / \mathrm{ml}$ ).

2. Antimycoplasmal Activity, Especially Activity against Macrolide-resistant Strains of Mycoplasma gallisepticum

Tylosin is currently used for the treatment of mycoplasma infections in animals. As shown in Table 2, 4"'-O-(phenylthio)acetyltylosin, 4"-O-(4-nitrophenylacetyl)tylosin and 4"-O-phenylsulfonylacetyltylosin showed an improved antimycoplasmal activity against macrolide-resistant strains. MIC values were $0.08 \mu \mathrm{g} / \mathrm{ml}$. It is interesting that the degree of the activity of derivatives in inhibiting mycoplasma resistant to tylosin is parallel to the antibacterial activity against resistant Staphylococcus strains. 3-OAcetyl-4" $-O$-isovaleryltylosin showed a strong inhibition against mycoplasma resistant to tylosin, but 3-O-acetyl-4"'-O-isovaleryl demycinosyl tylosin had no activity. Mycaminosyl tylonolide ${ }^{7)}$ which lacks both mycarose and mycinose moieties inhibited tylosin-sensitive mycoplasma, but had no activity against tylosin-resistant strains. But, this derivative had a stronger antibacterial activity against Gram-negative bacteria than tylosin: MIC against E. coli NIHJ was $50 \mu \mathrm{g} / \mathrm{ml}$, while that of tylosin was $200 \mu \mathrm{g} / \mathrm{ml}$.

3. Uptake of Tylosin Derivatives by Staphylococcus strain (MS-8710) Resistant to Tylosin and its Correlation to Antibacterial Activity

Introduction of an isovaleryl group onto the $4{ }^{\prime \prime}-\mathrm{OH}$ of tylosin enhanced the uptake of drug by the strain MS-8710. This alteration correlated well with the antibacterial activity of tylosin derivatives ${ }^{2}$. As reported previously, the ribosomes of $S$. aureus MS-9610 were resistant ${ }^{3)}$. In contrast, the ribosome 
Table 3. MIC, retention time in reverse phase column chromatography, Rf values in TLC and inhibition of uptake of $3-O-\left[1-{ }^{14} \mathrm{C}\right]$ acetyl- $4{ }^{\prime \prime}-O$-isovaleryltylosin and of $\left[{ }^{14} \mathrm{C}\right]$ leucine incorporation by intact cells of Staphylococcus aureus MS-8710.

\begin{tabular}{|c|c|c|c|c|c|c|c|}
\hline \multirow[b]{2}{*}{ No. } & \multirow{2}{*}{$\begin{array}{l}\text { Derivative } \\
\text { Structure at the } 4^{\prime \prime}-O \text { - }\end{array}$} & \multirow{2}{*}{$\begin{array}{c}\text { MIC } \\
(\mu \mathrm{g} / \mathrm{ml}) \\
\text { S. aureus } \\
\text { MS-8710 }\end{array}$} & \multirow{2}{*}{$\begin{array}{l}\text { Retention } \\
\text { time*1 } \\
\text { (minutes) }\end{array}$} & \multicolumn{2}{|c|}{$\mathrm{Rf}^{* 2}$} & \multicolumn{2}{|c|}{$\begin{array}{l}\% \text { Inhibition by a } \\
\text { compound of }\end{array}$} \\
\hline & & & & (1) & (2) & $\begin{array}{c}\text { Uptake of } \\
{ }^{14} \text { C-labeled } \\
\text { tylosin } \\
\text { derivative*3 }\end{array}$ & $\begin{array}{l}{\left[{ }^{14} \mathrm{C}\right] \text { Leucine }} \\
\text { incorporation }\end{array}$ \\
\hline 1 & $H$ (parent compound) & 800 & 3.22 & 1 & 1 & 15 & 30 \\
\hline 8 & $\mathrm{CO}-\mathrm{CH}_{3}$ & 100 & 3.66 & 3.5 & 4.7 & 34 & 33 \\
\hline 9 & $\mathrm{CO}-\mathrm{CH}_{2}-\mathrm{CH}_{2}-\mathrm{CH}_{3}$ & 25 & 4.90 & 5.6 & 6.3 & 54 & 76 \\
\hline 10 & $\mathrm{CO}-\mathrm{CH}_{2}-\mathrm{CH}\left(\mathrm{CH}_{3}\right)_{2}$ & 25 & 5.47 & 5.7 & 6.4 & 57 & 79 \\
\hline 12 & $\mathrm{CO}-\mathrm{CH}_{2}-\mathrm{CH}_{2}-\mathrm{CH}\left(\mathrm{CH}_{3}\right)_{2}$ & 12.5 & 7.15 & 6.2 & 6.8 & 59 & 85 \\
\hline 14 & $\mathrm{CO}-\left(\mathrm{CH}_{2}\right)_{4}-\mathrm{CH}_{3}$ & 25 & 7.45 & 6.2 & 6.8 & 58 & 81 \\
\hline 15 & $\mathrm{CO}-\left(\mathrm{CH}_{2}\right)_{6}-\mathrm{CH}_{3}$ & 25 & 13.35 & 6.3 & 7.1 & 66 & 62 \\
\hline 16 & $\mathrm{CO}-\left(\mathrm{CH}_{2}\right)_{3}-\mathrm{CH}_{3}$ & $>200^{* 5}$ & 27.91 & 6.8 & 7.4 & 50 & 11 \\
\hline 20 & & 6.25 & 4.65 & - & - & 54 & 88 \\
\hline 28 & $\mathrm{CO}-\mathrm{CH}$ & 6.25 & 5.88 & - & 一 & 55 & 82 \\
\hline 27 & $\mathrm{CO}-\mathrm{C}$ & 6.25 & 3.85 & - & - & 51 & 87 \\
\hline 46 & $\mathrm{SO}_{2}$ & 6.25 & 4.52 & - & - & 51 & 80 \\
\hline 48 & $\mathrm{SO}_{2}-$ & 6.25 & 5.20 & 一 & 一 & 53 & 82 \\
\hline
\end{tabular}

*1 Retention time: determined by HPLC with $\mathrm{C}_{18}$ reversed phase column, acetonitrile - $2 \%$ monoethanolamine in $\mathrm{H}_{2} \mathrm{O}=60: 40(\mathrm{v} / \mathrm{v})$.

*2 Rf: derivative/tylosin; (1) $n$-Hexane - acetone - MeOH - benzene - EtOAc, 30: 10: 8: 25: 20 (v/v)

(2) $\mathrm{CHCl}_{3}-\mathrm{MeOH}, 10: 1(\mathrm{v} / \mathrm{v})$

*3 \% Inhibition on uptake: Cells of $S$. aureus MS-8710, cultured in BHI medium for 6 hours with shaking, collected and suspended in $0.05 \mathrm{M}$ phosphate buffer, $\mathrm{pH} 7.0$, to give a cell density of $3.3 \mathrm{OD}_{680}$. Each $0.4 \mathrm{ml}$ of cell suspension mixed with $0.1 \mathrm{ml}$ of unlabeled tylosin derivatives solution dissolved in $10 \%$ $\mathrm{MeOH}(500 \mu \mathrm{g} / \mathrm{ml})$. After preincubation at $37^{\circ} \mathrm{C}$ for 10 minutes, $10 \mu \mathrm{l}$ of $3-O-\left[1-{ }^{14} \mathrm{C}\right]$ acetyl-4' $-O$-isovaleryltylosin $(1.84 \mu \mathrm{g}, 10.24 \mathrm{mCi} / \mathrm{mmole})$ added and incubated for 20 minutes. Cells filtered through Millipore filter disc (HA, $0.45 \mu \mathrm{m}$ ) and washed three times with each $3 \mathrm{ml}$ of cold buffer saline containing $50 \mu \mathrm{g} / \mathrm{ml}$ of unlabeled 3-O-acetyl-4"'-O-isovaleryltylosin. Radioactivity remaining on the filter disc was determined by the liquid-scintillation method.

*4 \% Inhibition of $\left[{ }^{14} \mathrm{C}\right]$ leucine incorporation into cellular macromolecules: Cells of S. aureus MS-8710, cultured in $\mathrm{BHI}$ medium for 7 hours $\left(\mathrm{OD}_{300}=0.62\right)$ with shaking, collected and suspended to one forth of the culture with $0.05 \mathrm{M}$ phosphate buffer, $\mathrm{pH} 7.0$, containing $1.0 \mathrm{M}$ sucrose and $0.15 \mathrm{M} \mathrm{NaCl}$. Each $90 \mu \mathrm{l}$ of cell suspension mixed with $10 \mu \mathrm{l}$ of unlabeled tylosin derivative aqueous solution to give a final concentration of $6.25 \mu \mathrm{g} / \mathrm{ml}$. After preincubation at $37^{\circ} \mathrm{C}$ for 10 minutes, $10 \mu 1$ of L-[U- $\left.{ }^{14} \mathrm{C}\right]$ leucine $(5 \mu \mathrm{Ci} / \mathrm{ml}, 351 \mathrm{mCi} / \mathrm{mmole})$ added and incubated at $37^{\circ} \mathrm{C}$ for 30 minutes. Radioactivity in cold TCA insoluble materials was determined by a toluene scintillation method as reported in a previous paper ${ }^{2)}$.

*5 Compound No. 16

The data obtained in 3 experiments for MIC and \% inhibition of the uptake of ${ }^{14} \mathrm{C}$-labeled tylosin derivative are as follows: $>200,>200,200 \mu \mathrm{g} / \mathrm{ml}$ for $\mathrm{MIC} ; 55,49,46 \%$ inhibition.

system of S. aureus MS-8710 is sensitive to tylosin and other macrolides and its resistance has been confirmed to be due to decreased permeability (the mechanism of macrolide-resistance of this strain will be reported elsewhere). As a parameter for the uptake of the compounds into the strain MS-8710, the 
Table 4. Effect of 4"- $O$-(phenylthio)acetyltylosin and 3-O-acetyl-4"- $O$-isovaleryltylosin on in vitro protein synthesis with ribosomes of MS-9610 and the binding of $3-O-\left[1-{ }^{14} \mathrm{C}\right]$ acetyl- $4^{\prime \prime}-O$-isovaleryltylosin to its ribosomes.

\begin{tabular}{|c|c|c|c|}
\hline \multirow{2}{*}{ Compound } & \multirow{2}{*}{$\begin{array}{c}\mathrm{MIC} \\
(\mu \mathrm{g} / \mathrm{ml})\end{array}$} & \multicolumn{2}{|c|}{$\%$ Inhibition } \\
\hline & & $\begin{array}{l}\text { In vitro protein } \\
\text { synthesis } * 1\end{array}$ & Binding of ${ }^{14} \mathrm{C}-* 2$ \\
\hline Tylosin & 1600 & 41 & 20.5 \\
\hline 3-O-Acetyl-4" $O$-isovaleryltylosin & 100 & 63 & 57 \\
\hline $4^{\prime \prime}-O$-(Phenylthio)acetyltylosin & 25 & 78.5 & 77 \\
\hline
\end{tabular}

inhibitory activities of unlabeled tylosin derivatives on uptake of $3-O-\left[1-{ }^{14} \mathrm{C}\right]$ acetyl-4" $-O$-isovaleryltylosin by cells and on $\left[{ }^{14} \mathrm{C}\right]$ leucine incorporation into cellular macromolecules were measured. Hydrophobicities of tylosin derivatives were measured by thin-layer chromatography (TLC) using silica gel plates and by high performance liquid chromatography (HPLC) using $\mathrm{C}_{18}$ reversed phase column. In the derivatives having the straight and branched-chain aliphatic acyl groups, 4 "'-O-decanoyltylosin (compound 16) had the decreased antibacterial activity and its retention time in HPLC was much longer than the other derivatives, as shown in Table 3. The activities of the derivatives having the side chain of from four to eight carbon atoms in inhibiting with the uptake of $3-O-\left[1-{ }^{14} \mathrm{C}\right]$ acetyl-4" $-O$-isovaleryltylosin by cells and $\left[{ }^{14} \mathrm{C}\right]$ leucine incorporation into cellular macromolecules were more than $50 \%$ and these derivatives showed stronger antibacterial activities than tylosin or $4^{\prime \prime}-O$-acetyltylosin. 4 "'-O-Octanoyltylosin (compound 15) showed the highest inhibitory activity on uptake of ${ }^{14} \mathrm{C}$-labeled tylosin derivative but inhibition of $\left[{ }^{14} \mathrm{C}\right]$ leucine incorporation into cellular macromolecules was lower than the other derivatives. $\quad 4$ " $-O$-Decanoyltylosin inhibited uptake to the extent of $50 \%$ but has an MIC $>200 \mu \mathrm{g} / \mathrm{ml}$. It seems that the ribosomes are resistant to this derivative, because the inhibitory activity by this compound on $\left[{ }^{14} \mathrm{C}\right]$ leucine incorporation was extremely low.

In spite of having more improved antibacterial activities, the inhibitory activities on uptake of ${ }^{14} \mathrm{C}$ labeled tylosin derivative by the derivatives having the substituent groups such as 4 "'-O-(4-nitrophenylacetyl)tylosin (20), 4"'-O-(phenylsulfonyl)acetyltylosin (27), 4"'-O-(phenylthio)acetyltylosin (28), 4"'-O(4-nitrophenylsulfonyl)tylosin (46) and $4^{\prime \prime}$ - $O$-phenylethanesulfonyltylosin (48) did not increase as compared with the aliphatic acyl derivatives, but similarly showed the high inhibitory activities on $\left[{ }^{14} \mathrm{C}\right]-$ leucine incorporation into cellular macromolecules. In the case of derivatives having the substituent groups containing cyclic structures, we could not find the correlation between the hydrophobicity and antibacterial activity of the derivatives. These derivatives having the aromatic groups also showed an improved antibacterial activity against $S$. aureus MS-9610 whose ribosomes were resistant. As shown in Table 4, 4" $O$-(phenylthio)acetyltylosin strongly inhibited both the protein synthesis in vivo and the binding of $3-O-\left[1-{ }^{14} \mathrm{C}\right]$ acetyl-4" $-O$-isovaleryltylosin to ribosomes of this strain. It indicates that the improved antibacterial activity of this derivative might be due to its strong binding to ribosomes.

\section{Experimental}

General Methods

Melting point, optical rotation and ${ }^{1} \mathrm{H}$ NMR $\left(\mathrm{CDCl}_{3}\right)$ spectra were measured by the same methods 
as described in a previous paper ${ }^{5)}$. Column chromatography was performed on Wakogel C-200. For analytical TLC plates Merck silica gel $60 \mathrm{~F}_{254}$ was used and macrolide spots were detected by spraying with $10 \%$ sulfuric acid. High performance liquid chromatography (HPLC) was performed on a reverse phase Radial-pak A column (Waters Associates, Inc.,) at room temperature using a Waters Liquid Chromatograph model ALC/GPC 244. The solvent used was a mixture of acetonitrile - $2 \%$ monoethanolamine in $\mathrm{H}_{2} \mathrm{O}(60: 40, \mathrm{v} / \mathrm{v}, 1 \mathrm{ml} /$ minute $)$ and effluents were monitered by $\mathrm{UV}_{280}$. Biological tests, such as, the measurement of the minimum inhibitory concentration (MIC, $\mu \mathrm{g} / \mathrm{ml}$ ), inhibition of the protein synthesis in vitro and in vivo and the effect on uptake of ${ }^{14} \mathrm{C}$-labeled tylosin derivative by intact cells of $S$. aureus MS-8710 were performed according to the methods described in previous papers ${ }^{1,2}$.

\section{2'-O-Acetyltylosin (2)}

To a solution of tylosin $(1)(1.0 \mathrm{~g})$ in acetone $(7 \mathrm{ml})$ was added potassium hydrogen carbonate $(1.0 \mathrm{~g})$ and under stirring at room temperature, acetyl chloride $(0.4 \mathrm{~g})$ in acetone $(0.3 \mathrm{ml})$ was added dropwise. The mixture was kept at room temperature for 5 hours. The mixture was poured into ice-water ( $30 \mathrm{ml})$ and then extracted twice each with $10 \mathrm{ml}$ of benzene. The benzene extract was washed twice with a saturated aqueous sodium hydrogen carbonate $\left(\mathrm{NaHCO}_{3}\right)$ solution $(50 \mathrm{ml})$, twice with a saturated aqueous sodium chloride $(\mathrm{NaCl})$ solution $(50 \mathrm{ml})$, dried over anhydrous sodium sulfate $\left(\mathrm{Na}_{2} \mathrm{SO}_{4}\right)$, and evaporated to dryness to give $2^{\prime}-O$-acetyltylosin $(2)(1.0 \mathrm{~g})$ which was crystallized from toluene. ${ }^{1} \mathrm{H} \mathrm{NMR}$, o $1.78\left(3 \mathrm{H}, \mathrm{s}, 12-\mathrm{CH}_{3}\right), 2.04,\left(3 \mathrm{H}, \mathrm{s}, 2^{\prime}-\mathrm{OCOCH}_{3}\right), 2.37\left(6 \mathrm{H}, \mathrm{s}, \mathrm{N}\left(\mathrm{CH}_{3}\right)_{2}\right), 3.46\left(3 \mathrm{H}, \mathrm{s}, \mathrm{OCH}_{3}\right), 3.58(3 \mathrm{H}$, $\left.\mathrm{s}, \mathrm{OCH}_{3}\right), 4.24\left(1 \mathrm{H}, \mathrm{d}, J_{1^{\prime}, 2^{\prime}}=7.5 \mathrm{~Hz}, \mathrm{H}-1^{\prime}\right), 4.54\left(1 \mathrm{H}, \mathrm{d}, J_{1^{\prime \prime \prime}, 2^{\prime \prime \prime}}=8 \mathrm{~Hz}, \mathrm{H}-1^{\prime \prime \prime}\right), 5.88\left(1 \mathrm{H}, \mathrm{d}, J_{13,14}=\right.$ $10.5 \mathrm{~Hz}, \mathrm{H}-13), 6.24\left(1 \mathrm{H}, \mathrm{d}, J_{10,11}=16 \mathrm{~Hz}, \mathrm{H}-10\right), 7.27\left(1 \mathrm{H}, \mathrm{d}, J_{10,11}=16 \mathrm{~Hz}, \mathrm{H}-11\right), 9.65(1 \mathrm{H}, \mathrm{s}, \mathrm{CHO})$. $\lambda_{\max }^{\mathrm{MeOH}} 284 \mathrm{~nm}\left(\mathrm{E}_{\mathrm{cm}}^{1 \%} 213\right)$.

Anal. Calcd. for $\mathrm{C}_{48} \mathrm{H}_{78} \mathrm{NO}_{18}$ (MW 957): C 60.17, H 8.31, N 1.46. Found:

C $60.50, \mathrm{H} 8.72, \mathrm{~N} 1.43$.

2'-O-Acetyl-4"' -O-monochloroacetyltylosin (3)

To a solution of $2(1.0 \mathrm{~g})$ in a mixture of methylene chloride $(20 \mathrm{ml})$ and pyridine $(0.16 \mathrm{~g})$ at $-15 \sim$ $-10^{\circ} \mathrm{C}$ was added chloroacetyl chloride $(0.28 \mathrm{~g})$ under stirring kept for 5 minutes, and then poured into a saturated aqueous toluene solution $(140 \mathrm{ml})$. The toluene layer was washed twice with $50 \mathrm{ml}$ of a saturated aqueous $\mathrm{NaHCO}_{3}$ solution and of a saturated aqueous $\mathrm{NaCl}$ solution, dried over anhydrous $\mathrm{Na}_{2} \mathrm{SO}_{4}$ and evaporated to dryness. The residue was dissolved in a small amount of benzene, placed on a column of silica gel $(1.8 \times 25 \mathrm{~cm})$, and eluted with a mixture of benzene - acetone (10:1). Effluents were collected in 5 -g fractions. Concentration of fractions $45 \sim 55$ gave 2 '- $O$-acetyl-4"' $O O$-monochloroacetyltylosin $(3)(0.62 \mathrm{~g})$, as a white powder. ${ }^{1} \mathrm{H}$ NMR, $\delta 1.80\left(3 \mathrm{H}, \mathrm{s}, 12-\mathrm{CH}_{3}\right), 2.06\left(3 \mathrm{H}, \mathrm{s}, 2^{\prime}-\mathrm{OCOCH}_{3}\right)$, $2.39\left(6 \mathrm{H}, \mathrm{s}, \mathrm{N}\left(\mathrm{CH}_{3}\right)_{2}\right), 3.48\left(3 \mathrm{H}, \mathrm{s}, \mathrm{OCH}_{3}\right), 3.52\left(3 \mathrm{H}, \mathrm{s}, \mathrm{OCH}_{3}\right), 4.09\left(2 \mathrm{H}, \mathrm{s}, 4^{\prime \prime \prime}-\mathrm{OCOCH}_{2} \mathrm{Cl}\right), 4.64(1 \mathrm{H}, \mathrm{d}$, $\left.J_{1^{\prime \prime \prime}, 2^{\prime \prime \prime}}=7.5 \mathrm{~Hz}, \mathrm{H}-1^{\prime \prime \prime}\right), 5.91\left(1 \mathrm{H}, \mathrm{d}, J_{13,14}=10.5 \mathrm{~Hz}, \mathrm{H}-13\right), 6.29\left(1 \mathrm{H}, \mathrm{d}, J_{10,11}=16 \mathrm{~Hz}, \mathrm{H}-10\right), 7.34$ $\left(1 \mathrm{H}, \mathrm{d}, J_{10,11}=16 \mathrm{~Hz}, \mathrm{H}-11\right), 9.70(1 \mathrm{H}, \mathrm{s}, \mathrm{CHO}) . \quad \lambda_{\max }^{\mathrm{MeOH}} 284 \mathrm{~nm}\left(\mathrm{E}_{1 \mathrm{~cm}}^{1 \%} 165\right)$.

Anal. Calcd. for $\mathrm{C}_{50} \mathrm{H}_{80} \mathrm{NO}_{19} \mathrm{Cl}$ (MW 1,034): C 58.04, H 7.79, N 1.35. Found:

C 58.24, H 7.57, N 1.39 .

2'-O-Acetyl-4"' -O-trichloroacetyltylosin (4)

To a solution of $2(1.0 \mathrm{~g})$ in a mixture of methylene chloride $(20 \mathrm{ml})$ and pyridine $(0.22 \mathrm{~g})$ at $-15 \sim$ $-10^{\circ} \mathrm{C}$ was added trichloroacetyl chloride $(0.70 \mathrm{~g}), 2^{\prime}$ - $O$-acetyl-4"' $-O$-trichloroacetyltylosin $(0.75 \mathrm{~g})$ was obtained by the same procedures as described in the preparation of $3 .{ }^{1} \mathrm{H}$ NMR, $\delta 1.80\left(3 \mathrm{H}, \mathrm{s}, 12-\mathrm{CH}_{3}\right)$, $2.06\left(3 \mathrm{H}, \mathrm{s}, 2^{\prime}-\mathrm{OCOCH}_{3}\right), 2.40\left(6 \mathrm{H}, \mathrm{s}, \mathrm{N}\left(\mathrm{CH}_{3}\right)_{2}\right), 3.52\left(3 \mathrm{H}, \mathrm{s}, \mathrm{OCH}_{3}\right), 3.56\left(3 \mathrm{H}, \mathrm{s}, \mathrm{OCH}_{3}\right), 4.69(1 \mathrm{H}, \mathrm{d}$, $\left.J_{1^{\prime \prime}{ }^{\prime}, 2^{\prime \prime}}=8 \mathrm{~Hz}, \mathrm{H}-1^{\prime \prime \prime}\right), 5.95\left(1 \mathrm{H}, \mathrm{d}, J_{13,14}=10.5 \mathrm{~Hz}, \mathrm{H}-13\right), 6.32\left(1 \mathrm{H}, \mathrm{d}, J_{10,11}=16 \mathrm{~Hz}, \mathrm{H}-10\right), 7.37(1 \mathrm{H}$, d, $\left.J_{10,11}=16 \mathrm{~Hz}, \mathrm{H}-11\right), 9.73(1 \mathrm{H}, \mathrm{s}, \mathrm{CHO}) . \quad \lambda_{\max }^{\mathrm{MeOH}} 283 \mathrm{~nm}\left(\mathrm{E}_{1 \mathrm{~cm}}^{1 \%} 196\right)$.

Anal. Calcd. for $\mathrm{C}_{50} \mathrm{H}_{78} \mathrm{NO}_{19} \mathrm{Cl}_{3}$ (MW 1,103): C 54.42, $\mathrm{H}$ 7.12, N 1.27. Found:

C 54.21, H 7.43, N 1.31 .

$3,2^{\prime}$-Di- $O$-acetyltylosin (5)

3-O-Acetyltylosin $(1.0 \mathrm{~g})$ was mixed with acetic anhydride $(5 \mathrm{ml})$, the resulting mixture was stirred to dissolve completely for about 30 seconds at room temperature and thereafter poured into ice-water $(45 \mathrm{ml})$ and extracted twice with $100 \mathrm{ml}$ of benzene, after the $\mathrm{pH}$ was adjusted to 8 with $\mathrm{NaHCO}_{3}$. After washing with a saturated aqueous $\mathrm{NaHCO}_{3}$ solution and a saturated $\mathrm{NaCl}$ solution, drying over anhydr- 
ous $\mathrm{Na}_{2} \mathrm{SO}_{4}$ and evaporation of the solvent, 3,2'-di- $O$-acetyltylosin (5) (1.0 g), obtained and crystallized from carbon tetrachloride. ${ }^{1} \mathrm{H}$ NMR, $\delta 1.79\left(3 \mathrm{H}, \mathrm{s}, 12-\mathrm{CH}_{3}\right), 2.04\left(3 \mathrm{H}, \mathrm{s}, 2^{\prime}-\mathrm{OCOCH}_{3}\right), 2.09(3 \mathrm{H}, \mathrm{s}$, $\left.3-\mathrm{OCOCH}_{3}\right), 2.37\left(6 \mathrm{H}, \mathrm{s}, \mathrm{N}\left(\mathrm{CH}_{3}\right)_{2}\right), 3.43\left(3 \mathrm{H}, \mathrm{s}, \mathrm{OCH}_{3}\right), 3.58\left(3 \mathrm{H}, \mathrm{s}, \mathrm{OCH}_{3}\right), 4.18\left(1 \mathrm{H}, \mathrm{d}, J_{1^{\prime}, 2^{\prime}}=7.5 \mathrm{~Hz}\right.$, $\left.\mathrm{H}-1^{\prime}\right), 4.53\left(1 \mathrm{H}, \mathrm{d}, J_{1^{\prime \prime} \prime}, 2^{\prime \prime \prime}=7.5 \mathrm{~Hz}, \mathrm{H}-1^{\prime \prime \prime}\right), 5.90\left(1 \mathrm{H}, \mathrm{d}, J_{13,14}=10.5 \mathrm{~Hz}, \mathrm{H}-13\right), 6.25\left(1 \mathrm{H}, \mathrm{d}, J_{10,11}=\right.$ $16 \mathrm{~Hz}, \mathrm{H}-10), 7.38\left(1 \mathrm{H}, \mathrm{d}, J_{10,11}=16 \mathrm{~Hz}, \mathrm{H}-11\right), 9.62(1 \mathrm{H}, \mathrm{s}, \mathrm{CHO}) . \quad \lambda_{\max }^{\mathrm{MeOH}} 282 \mathrm{~nm}\left(\mathrm{E}_{1 \mathrm{~cm}}^{1 \%} 207\right)$.

Anal. Calcd. for $\mathrm{C}_{50} \mathrm{H}_{81} \mathrm{NO}_{19}$ (MW 999): C 60.04, H 8.16, N 1.40. Found: C $59.71, \mathrm{H} 8.33, \mathrm{~N} 1.36$.

3,2'-Di- $O$-acetyl-4"' - $O$-monochloroacetyltylosin (6)

To a solution of $5(1.0 \mathrm{~g})$ in a mixture of methylene chloride $(20 \mathrm{ml})$ and pyridine $(0.15 \mathrm{~g})$ at $-15 \sim$ $-10^{\circ} \mathrm{C}$ was added chloroacetyl chloride $(0.27 \mathrm{~g})$. By the same procedure as described in the preparation of 3, 3,2'-di- $O$-acetyl-4"' $-O$-monochloroacetyltylosin (6) was obtained as a white powder $(0.60 \mathrm{~g})$. ${ }^{1} \mathrm{H}$ NMR, $\delta 1.79\left(3 \mathrm{H}, \mathrm{s}, 12-\mathrm{CH}_{3}\right), 2.05\left(3 \mathrm{H}, \mathrm{s}, 2^{\prime}-\mathrm{OCOCH}_{3}\right), 2.09\left(3 \mathrm{H}, \mathrm{s}, 3-\mathrm{OCOCH}_{3}\right), 2.40(6 \mathrm{H}, \mathrm{s}, \mathrm{N}-$ $\left.\left(\mathrm{CH}_{3}\right)_{2}\right), 3.43\left(3 \mathrm{H}, \mathrm{s}, \mathrm{OCH}_{3}\right), 3.50\left(3 \mathrm{H}, \mathrm{s}, \mathrm{OCH}_{3}\right), 4.05\left(2 \mathrm{H}, \mathrm{s}, 4^{\prime \prime \prime}-\mathrm{OCOCH}_{2} \mathrm{Cl}\right), 4.60\left(1 \mathrm{H}, \mathrm{d}, J_{1^{\prime \prime \prime}, 2^{\prime \prime \prime}=}=\right.$ $\left.8.5 \mathrm{~Hz}, \mathrm{H}-1^{\prime \prime \prime}\right), 5.90\left(1 \mathrm{H}, \mathrm{d}, J_{13,14}=10.5 \mathrm{~Hz}, \mathrm{H}-13\right), 6.26\left(1 \mathrm{H}, \mathrm{d}, J_{10,11}=16 \mathrm{~Hz}, \mathrm{H}-10\right), 7.37\left(1 \mathrm{H}, \mathrm{d}, J_{10,11}=\right.$ $16 \mathrm{~Hz}, \mathrm{H}-11), 9.63(1 \mathrm{H}, \mathrm{s}, \mathrm{CHO}) . \quad \lambda_{\max }^{\mathrm{MeOH}} 283 \mathrm{~nm}\left(\mathrm{E}_{1 \mathrm{~cm}}^{1 \%} 204\right)$.

Anal. Calcd. for $\mathrm{C}_{52} \mathrm{H}_{82} \mathrm{NO}_{20} \mathrm{Cl}(\mathrm{MW} 1,075)$ : C 58.01, H 7.68, N 1.30 . Found:

C 58.38, H 7.90, N 1.25 .

3,2'-Di-O-acetyl-4'"'-O-trichloroacetyltylosin (7)

This compound was prepared by the same processes of the preparation of 6 , reacting $5(1.0 \mathrm{~g})$ with trichloroacetyl chloride $(0.73 \mathrm{~g})$ instead of chloroacetyl chloride. ${ }^{1} \mathrm{H}$ NMR, $\delta 1.82\left(3 \mathrm{H}, \mathrm{s}, 12-\mathrm{CH}_{3}\right)$, $2.06\left(3 \mathrm{H}, \mathrm{s}, 2^{\prime}-\mathrm{OCOCH}_{3}\right), 2.09\left(3 \mathrm{H}, \mathrm{s}, 3-\mathrm{OCOCH}_{3}\right), 2.38\left(6 \mathrm{H}, \mathrm{s}, \mathrm{N}\left(\mathrm{CH}_{3}\right)_{2}\right), 3.45\left(3 \mathrm{H}, \mathrm{s}, \mathrm{OCH}_{3}\right), 3.51$ $\left(3 \mathrm{H}, \mathrm{s}, \mathrm{OCH}_{3}\right), 4.63\left(1 \mathrm{H}, \mathrm{d}, J_{1^{\prime \prime \prime}, 2^{\prime \prime \prime}}=8 \mathrm{~Hz}, \mathrm{H}-1^{\prime \prime \prime}\right), 5.91\left(1 \mathrm{H}, \mathrm{d}, J_{13,14}=10.5 \mathrm{~Hz}, \mathrm{H}-13\right), 6.26(1 \mathrm{H}, \mathrm{d}$, $\left.J_{10,11}=16 \mathrm{~Hz}, \mathrm{H}-10\right), 7.39\left(1 \mathrm{H}, \mathrm{d}, J_{10,11}=16 \mathrm{~Hz}, \mathrm{H}-11\right), 9.63(1 \mathrm{H}, \mathrm{s}, \mathrm{CHO}) . \quad \lambda_{\max }^{\mathrm{MeOH}} 282 \mathrm{~nm}\left(\mathrm{E}_{1 \mathrm{~cm}}^{1 \%} 191\right)$.

Anal. Calcd. for $\mathrm{C}_{52} \mathrm{H}_{80} \mathrm{NO}_{20} \mathrm{Cl}_{3}$ (MW 1,145): C 54.52, $\mathrm{H}$ 7.04, N 1.22. Found:

C 54.37, H 7.49, N 1.28.

4"-O-Hexanoyltylosin (14) (General Method a)

To a solution of $3(200 \mathrm{mg})$ in pyridine $(2 \mathrm{ml})$ was added hexanoic anhydride $(1.96 \mathrm{ml})$ and the resulting mixture was kept at $5^{\circ} \mathrm{C}$ for 48 hours. Benzene $(100 \mathrm{ml})$ was added, and after washing twice with a saturated aqueous solution of $\mathrm{NaHCO}_{3}$ and $\mathrm{NaCl}$ and drying over anhydrous $\mathrm{Na}_{2} \mathrm{SO}_{4}$, the benzene extract was concentrated to dryness. The residue was dissolved in a small amount of benzene and applied to a column of silica gel $(1.7 \times 15 \mathrm{~cm})$, which was developed with a mixture of benzene - acetone (9: 1). Effluents were collected in 2 -g fractions, and evaporation of solvent from fractions $25 \sim 30$ gave 2'-O-acetyl-4"' $O$-monochloroacetyl-4"'-O-hexanoyltylosin $(85 \mathrm{mg})$ as a white powder. Selective ester hydrolysis of a derivative was carried out by refluxing in methanol $(10 \mathrm{ml})$ for 22 hours and concentrating to dryness; chromatography over silica gel $(1.7 \times 17 \mathrm{~cm})$, developing with benzene - acetone $(4: 1)$ and evaporation to dryness gave $4^{\prime \prime}-O$-hexanoyltylosin (14) $(60 \mathrm{mg})$. ${ }^{1} \mathrm{H}$ NMR, $\delta 1.79\left(3 \mathrm{H}, \mathrm{s}, 12-\mathrm{CH}_{3}\right)$, $2.52\left(6 \mathrm{H}, \mathrm{s}, \mathrm{N}\left(\mathrm{CH}_{3}\right)_{2}\right), 3.49\left(3 \mathrm{H}, \mathrm{s}, \mathrm{OCH}_{3}\right), 3.62\left(3 \mathrm{H}, \mathrm{s}, \mathrm{OCH}_{3}\right), 4.57\left(1 \mathrm{H}, \mathrm{d}, J_{1^{\prime \prime \prime}, 2^{\prime \prime \prime}}=8 \mathrm{~Hz}, \mathrm{H}-1^{\prime \prime \prime}\right)$, $4.59\left(1 \mathrm{H}, \mathrm{d}, J_{4^{\prime \prime}, 5^{\prime \prime}}=10 \mathrm{~Hz}, \mathrm{H}-4^{\prime \prime}\right), 5.92\left(1 \mathrm{H}, \mathrm{d}, J_{13,14}=10.5 \mathrm{~Hz}, \mathrm{H}-13\right), 6.26\left(1 \mathrm{H}, \mathrm{d}, J_{10,11}=16 \mathrm{~Hz}\right.$, $\mathrm{H}-10), 7.35\left(1 \mathrm{H}, \mathrm{d}, J_{10,11}=16 \mathrm{~Hz}, \mathrm{H}-11\right), 9.71(1 \mathrm{H}, \mathrm{s}, \mathrm{CHO}) . \quad \lambda_{\max }^{\mathrm{MeOH}} 283 \mathrm{~nm}\left(\mathrm{E}_{1 \mathrm{em}}^{1 \%} 206\right)$.

Table 5. Reaction conditions for synthesis of $4^{\prime \prime}-O$-substituted tylosin derivatives (General Method a).

\begin{tabular}{|c|c|c|c|c|c|c|c|}
\hline \multicolumn{2}{|r|}{ Product } & \multicolumn{5}{|c|}{ Conditions } & \multirow{2}{*}{$\begin{array}{l}\text { Yield } \\
(\%)\end{array}$} \\
\hline No. & Name & Acid anhydride (ml) & & $\begin{array}{l}\text { Pyridine } \\
(\mathrm{ml})\end{array}$ & $\begin{array}{l}\text { Temperature } \\
\left({ }^{\circ} \mathrm{C}\right)\end{array}$ & $\begin{array}{c}\text { Time } \\
\text { (hours) }\end{array}$ & \\
\hline 12 & $4^{\prime \prime}-O$-(4-Methylvaleryl)tylosin & 4-Methylvaleric anhydride & $(2.0)$ & 2 & 5 & 48 & 35 \\
\hline 14 & 4"-O-Hexanoyltylosin & Hexanoic anhydride & $(1.96)$ & 2 & 5 & 48 & 30 \\
\hline 15 & $4^{\prime \prime}-O$-Octanoyltylosin & Octanoic anhydride & $(2.5)$ & 2 & 5 & 48 & 48 \\
\hline 16 & 4"-O-Decanoyltylosin & Decanoic anhydride & $(3.0)$ & 2 & 5 & 50 & 40 \\
\hline 24 & $\begin{array}{l}4^{\prime \prime}-O-(3-\text { Cyclohexylpropionyl)- } \\
\text { tylosin }\end{array}$ & $\begin{array}{l}\text { 3-Cyclohexanepropionic } \\
\text { anhydride }\end{array}$ & $(3.5)$ & 2 & 5 & 22 & 40 \\
\hline
\end{tabular}


Table 6. Reaction conditions for synthesis of $4^{\prime \prime}-O$-substituted tylosin derivatives (General Method b).

\begin{tabular}{|c|c|c|c|c|c|c|c|}
\hline \multirow[b]{2}{*}{ No. } & \multirow[b]{2}{*}{$\begin{array}{l}\text { Product } \\
\qquad \text { Name }\end{array}$} & \multicolumn{5}{|c|}{ Conditions } & \multirow[b]{2}{*}{$\begin{array}{l}\text { Yield } \\
(\%)\end{array}$} \\
\hline & & $\begin{array}{l}\text { Carboxylic } \\
\text { acid } \\
\text { chloride } \\
\text { (mg) }\end{array}$ & $\begin{array}{l}\text { Pyridine } \\
\text { (mg) }\end{array}$ & $\begin{array}{l}\text { Tempe- } \\
\text { rature } \\
\left({ }^{\circ} \mathrm{C}\right)\end{array}$ & $\begin{array}{c}\text { Time } \\
\text { (minutes) }\end{array}$ & $\begin{array}{c}\text { Methylene } \\
\text { chloride } \\
(\mathrm{ml})\end{array}$ & \\
\hline 8 & 4"'-O-Acetyltylosin & 169 & 265 & -15 & 270 & 4.5 & 29 \\
\hline 11 & $4^{\prime \prime}-O-(2-$ Methoxy)isovaleryltylosin & 145 & 85 & $-10 \sim-5$ & 30 & 5 & 7 \\
\hline 13 & 4"'-O-(4-Methyl)valeryltylosin & 260 & 293 & $-5 \rightarrow 25$ & 2,460 & $5(\mathrm{THF})^{*}$ & 35 \\
\hline 17 & 4"'-O-Benzoyltylosin & 288 & 753 & $-10 \sim-5$ & 30 & 2 & 33 \\
\hline 18 & $4^{\prime \prime}-O-(2-$ Furoyl)tylosin & 316 & 287 & $-10 \sim-5$ & 36 & 5 & 74 \\
\hline 19 & 4"'-O-Phenylacetyltylosin & 115 & 88 & $-20 \sim-15$ & 60 & 6 & 6 \\
\hline 20 & 4"'-O-(4-Nitrophenylacetyl)tylosin & 181 & 110 & 0 & 40 & 3 & 29 \\
\hline 21 & $4^{\prime \prime}-O-(\alpha-$ Naphthyl)acetyltylosin & 264 & 137 & $-10 \sim-5$ & 20 & 4 & 30 \\
\hline 22 & $4^{\prime \prime}-O-(2-T h i e n y l)$ acetyltylosin & 155 & 117 & $0 \rightarrow 25$ & 1,080 & 2.5 & 44 \\
\hline 23 & $4^{\prime \prime}-O$-(3-Phenylpropionyl)tylosin & 120 & 460 & $-10 \sim-5$ & 30 & 2 & 44 \\
\hline 25 & 4"-O-Phenoxyacetyltylosin & 132 & 88 & $-10 \sim-5$ & 60 & 5 & 31 \\
\hline 26 & $4^{\prime \prime}-O-(\beta-N a p h t h o x y)$ acetyltylosin & 180 & 88 & $-10 \sim-5$ & 15 & 4 & 45 \\
\hline 27 & $4^{\prime \prime}-O$-(Phenylsulfonyl)acetyltylosin & 198 & 108 & -5 & 12 & 6 & 33 \\
\hline 28 & $4^{\prime \prime}-O$-(Phenylthio)acetyltylosin & 204 & 137 & $-10 \sim-5$ & 1,200 & 5 & 20 \\
\hline 31 & 4"-O-(4-Methylphenylthio)acetyltylosin & 300 & 240 & -5 & 120 & 2.5 & 8 \\
\hline 33 & $\begin{array}{l}\text { 4"-O-(Pentachlorophenylthio)- } \\
\text { acetyltylosin }\end{array}$ & 491 & 162 & $-15 \sim-10$ & 180 & 2.5 & 20 \\
\hline 34 & $4^{\prime \prime}-O$-(3-Phenylthio)propionyltylosin & 204 & 127 & $-10 \sim-5$ & 1,200 & 5 & 15 \\
\hline 36 & $\begin{array}{l}\text { 3-O-Acetyl-4" }-O \text {-(dimethylamino)- } \\
\text { acetyltylosin }\end{array}$ & 104 & 138 & 5 & 2,880 & 9 & 24 \\
\hline 41 & $\begin{array}{l}\text { 3-O-Acetyl-4"'-O-(1,2-dithiolane-3- } \\
\text { valeryl)tylosin }\end{array}$ & 245 & 205 & 5 & 1,200 & 4.5 & 13 \\
\hline 42 & $\begin{array}{l}\text { 3-O-Acetyl-4"'-O-D-(2-hydroxyphenyl- } \\
\text { acetyl)tylosin }\end{array}$ & 215 & 103 & -5 & 90 & 4.5 & 56 \\
\hline 43 & $\begin{array}{l}\text { 3-O-Acetyl-4"'-O-D-(2-acetoxyphenyl- } \\
\text { acetyl)tylosin }\end{array}$ & 185 & 103 & -5 & 120 & 4 & 51 \\
\hline
\end{tabular}

* Tetrahydrofuran (THF) used instead of methylene chloride.
Anal. Calcd. for $\mathrm{C}_{52} \mathrm{H}_{87} \mathrm{NO}_{18}(\mathrm{MW} \mathrm{1,013):}$
C 61.58, H 8.65, N 1.38.
Found:
C 61.80, H 8.93, N 1.41 .

Tylosin derivatives listed in Table 5 were prepared by treatment of $200 \mathrm{mg}$ of $\mathbf{3}$ or $\mathbf{6}$ with the corresponding acid anhydride in the presence of pyridine according to the General Method a under the conditions shown in Table 5.

\section{4'-O-(3-Phenylpropionyl)tylosin (23) (General Method b)}

A solution of $3(200 \mathrm{mg})$ in a mixture of methylene chloride $(2 \mathrm{ml})$ and pyridine $(460 \mathrm{mg})$ at $-10^{\circ} \mathrm{C}$ was allowed to react with 3-phenylpropionyl chloride $(0.1 \mathrm{ml})$ at $-10 \sim-5^{\circ} \mathrm{C}$ for 30 minutes. By the same procedures of preparation of 14, 4" $-O$-(3-phenylpropionyl)tylosin $(87 \mathrm{mg})$ was obtained. ${ }^{1} \mathrm{H}$ NMR, $\delta 1.79\left(3 \mathrm{H}, \mathrm{s}, 12-\mathrm{CH}_{3}\right), 2.49\left(6 \mathrm{H}, \mathrm{s}, \mathrm{N}\left(\mathrm{CH}_{3}\right)_{2}\right), 3.47\left(3 \mathrm{H}, \mathrm{s}, \mathrm{OCH}_{3}\right), 3.60\left(3 \mathrm{H}, \mathrm{s}, \mathrm{OCH}_{3}\right), 4.55(1 \mathrm{H}$, $\left.\mathrm{d}, J_{4^{\prime \prime}},_{5^{\prime \prime}}=10 \mathrm{~Hz}, \mathrm{H}-4^{\prime \prime}\right), 5.88\left(1 \mathrm{H}, \mathrm{d}, J_{13,14}=10.5 \mathrm{~Hz}, \mathrm{H}-13\right), 6.23\left(1 \mathrm{H}, \mathrm{d}, J_{10,11}=16 \mathrm{~Hz}, \mathrm{H}-10\right), 7.10 \sim$ $7.43\left(6 \mathrm{H}, \mathrm{m}, \mathrm{H}-11\right.$ and aromatic), $9.70(1 \mathrm{H}, \mathrm{s}, \mathrm{CHO}) . \quad \lambda_{\max }^{\mathrm{MeOH}} 283 \mathrm{~nm}\left(\mathrm{E}_{1 \mathrm{~cm}}^{1 \%} 210\right)$.
Anal. Calcd. for $\mathrm{C}_{55} \mathrm{H}_{85} \mathrm{NO}_{13}$ (MW 1,047):
Found:
C 63.02, H 8.17, N 1.34.
C 63.57, H 8.69, N 1.40 .

The carboxylic acid ester derivatives listed in Table 6 were prepared by treatment of $200 \mathrm{mg}$ of $\mathbf{3}$, 4, 6 or 7 with the corresponding carboxylic acid chloride according to the General Method b under the conditions shown in Table 6. When the 2-hydroxy or 3-hydroxy carboxylic acid chlorides were used, 
these hydroxyl groups were protected with a suitable blocking substituent group such as monochloroacetyl group, prior to the use for the reaction.

\section{4"-O-Phenylthioethanesulfonyltylosin (49) (General Method b)}

A solution of $4(250 \mathrm{mg})$ in methylene chloride $(6 \mathrm{ml})$ was mixed with triethylamine $(230 \mathrm{mg})$ and cooled to $-15^{\circ} \mathrm{C}$. To the resulting solution was added phenylthioethanesulfonyl chloride $(520 \mathrm{mg})$ and the solution was reacted with stirring at $-15^{\circ} \mathrm{C}$ for 17 hours and poured into benzene $(100 \mathrm{ml})$. By the same procedures described in the preparation of 14, 4'-O-phenylthioethanesulfonyltylosin $(58 \mathrm{mg})$ was obtained. ${ }^{1} \mathrm{H}$ NMR, $\delta 1.82\left(3 \mathrm{H}, \mathrm{s}, 12-\mathrm{CH}_{3}\right), 2.50\left(6 \mathrm{H}, \mathrm{s}, \mathrm{N}\left(\mathrm{CH}_{3}\right)_{2}\right)$, around $3.41\left(4 \mathrm{H}, \mathrm{SCH}_{2} \mathrm{CH}_{2} \mathrm{SO}_{2}\right)$, $3.51\left(3 \mathrm{H}, \mathrm{s}, \mathrm{OCH}_{3}\right), 3.63\left(3 \mathrm{H}, \mathrm{s}, \mathrm{OCH}_{3}\right), 5.93\left(1 \mathrm{H}, \mathrm{d}, J_{13,14}=10.5 \mathrm{~Hz}, \mathrm{H}-13\right), 6.28\left(1 \mathrm{H}, \mathrm{d}, J_{10,11}=16 \mathrm{~Hz}\right.$, $\mathrm{H}-10), 7.23 \sim 7.41$ (6H, m, H-11 and aromatic), $9.73(1 \mathrm{H}, \mathrm{s}, \mathrm{CHO}) . \lambda_{\max }^{\mathrm{MeOH}} 283 \mathrm{~nm}\left(\mathrm{E}_{1 \mathrm{~cm}}^{1 \%} 171\right)$.

Anal. Calcd. for $\mathrm{C}_{54} \mathrm{H}_{85} \mathrm{NO}_{19} \mathrm{~S}_{2}$ (MW 1,115): C 58.09, $\mathrm{H} 7.67, \mathrm{~N} 1.25$.

$$
\text { Found: } \quad \text { C 57.90, H 7.93, N 1.24. }
$$

Sulfonic acid ester derivatives listed in Table 7 were prepared by treatment of $250 \mathrm{mg}$ of $\mathbf{3}$ or $\mathbf{4}$ with corresponding sulfonic acid chlorides according to the General Method b under the conditions shown in Table 7.

\begin{tabular}{|c|c|c|c|c|c|c|c|c|}
\hline \multirow[b]{2}{*}{ No. } & \multirow[b]{2}{*}{$\begin{array}{l}\text { Product } \\
\text { Name }\end{array}$} & \multicolumn{6}{|c|}{ Conditions } & \multirow[b]{2}{*}{$\begin{array}{l}\text { Yield } \\
(\%)\end{array}$} \\
\hline & & $\begin{array}{l}\text { Sulfonic } \\
\text { acid } \\
\text { chloride } \\
\text { (mg) }\end{array}$ & $\begin{array}{l}\text { Pyridine } \\
(\mathrm{ml})\end{array}$ & $\begin{array}{l}\text { Triethyl- } \\
\text { amine } \\
\text { (mg) }\end{array}$ & $\begin{array}{c}\text { Tempe- } \\
\text { rature } \\
\left({ }^{\circ} \mathrm{C}\right)\end{array}$ & $\begin{array}{l}\text { Time } \\
\text { (hours) }\end{array}$ & $\begin{array}{l}\text { Methylene } \\
\text { chloride } \\
\text { (ml) }\end{array}$ & \\
\hline 44 & $\begin{array}{l}4^{\prime \prime}-O-(\alpha-N a p h t h a l e n e s u l f o n y l)- \\
\text { tylosin }\end{array}$ & 420 & 3.3 & - & -15 & 18 & - & 26 \\
\hline 45 & $4^{\prime \prime}$-O-Phenylsulfonyltylosin & 386 & 3.0 & - & -15 & 17 & - & 24 \\
\hline 46 & $\begin{array}{l}4^{\prime \prime}-O \text {-(4-Nitrophenylsulfonyl)- } \\
\text { tylosin }\end{array}$ & 504 & 3.3 & - & $-15 \rightarrow 25$ & 2 & - & 22 \\
\hline 47 & $\begin{array}{l}\text { 4"'-O-Phenylmethanesulfonyl- } \\
\text { tylosin }\end{array}$ & 130 & 0.1 & - & $-15 \rightarrow-5$ & 24 & 5 & 24 \\
\hline 48 & 4"-O-Phenylethanesulfonyltylosin & 270 & - & 150 & -15 & 17 & 6 & 16 \\
\hline 49 & $\begin{array}{l}4^{\prime \prime} \text {-O-Phenylthioethanesulfonyl- } \\
\text { tylosin }\end{array}$ & 520 & - & 230 & -15 & 17 & 6 & 23 \\
\hline
\end{tabular}

Table 7. Reaction conditions for synthesis of 4 "- $O$-substituted tylosin derivatives (General Method b).

\begin{tabular}{|c|c|c|c|c|c|c|c|}
\hline \multirow[b]{2}{*}{ No. } & \multirow{2}{*}{$\begin{array}{l}\text { Product } \\
\text { Name }\end{array}$} & \multicolumn{5}{|c|}{ Conditions } & \multirow[b]{2}{*}{$\begin{array}{l}\text { Yield } \\
(\%)\end{array}$} \\
\hline & & $\begin{array}{c}\text { Carboxylic } \\
\text { acid } \\
(\mathrm{mg})\end{array}$ & $\begin{array}{l}\text { Pyridine } \\
\text { (mg) }\end{array}$ & $\begin{array}{l}\text { Tempe- } \\
\text { rature } \\
\left({ }^{\circ} \mathrm{C}\right)\end{array}$ & $\begin{array}{l}\text { Time } \\
\text { (hours) }\end{array}$ & $\begin{array}{c}\text { Methylene } \\
\text { chloride } \\
(\mathrm{ml})\end{array}$ & \\
\hline 29 & $4 "-O-($ Cyclohexylthio)acetyltylosin & 236 & 430 & $-10 \rightarrow 4$ & 20 & 2.5 & 40 \\
\hline 30 & $4 " \prime-O$-(4-Pyridyl)thioacetyltylosin & 204 & 342 & $-10 \rightarrow 4$ & 21 & 8 & 20 \\
\hline 32 & $4^{\prime \prime}-O-(4-C h l o r o p h e n y l t h i o)$ acetyltylosin & 330 & 516 & 5 & 20 & 5 & 23 \\
\hline 35 & 3-O-Acetyl-4"'-O-(3-pyridyl)acetyltylosin & 153 & 368 & $-10 \rightarrow 4$ & 21 & 8 (THF)* & 33 \\
\hline 37 & 3-O-Acetyl-4"'-O-molpholinoacetyltylosin & 500 & 862 & $-10 \rightarrow 4$ & 44 & 4 & 72 \\
\hline 38 & $\begin{array}{l}\text { 3-O-Acetyl-4"'-O-(4-methylpiperazino- } \\
\text { acetyl)tylosin }\end{array}$ & 350 & 862 & $-10 \rightarrow 4$ & 44 & 4 & 36 \\
\hline 39 & $\begin{array}{l}\text { 3-O-Acetyl-4"'-O-(1-imidazolylpropionyl)- } \\
\text { tylosin }\end{array}$ & 169 & 414 & $-10 \rightarrow 25$ & 48 & 4 & 17 \\
\hline 40 & $\begin{array}{l}\text { 3-O-Acetyl-4" }-O \text {-(1-triazolylpropionyl)- } \\
\text { tylosin }\end{array}$ & 185 & 414 & $-10 \rightarrow 25$ & 24 & 4 & 32 \\
\hline
\end{tabular}

Table 8. Reaction conditions for synthesis of 4"-O-substituted tylosin derivatives (General Method c).

* Tetrahydrofuran (THF) used instead of methylene chloride. 
4"-O-(Cyclohexylthio)acetyltylosin (29) (General Method c)

Cyclohexylthioacetic acid $(236 \mathrm{mg})$ and triethylamine $(138 \mathrm{mg})$ were dissolved in methylene chloride $(2.5 \mathrm{ml})$ and cooled to $-10^{\circ} \mathrm{C}$. To the solution was added pivaloyl chloride $(164 \mathrm{mg})$ and the solution was reacted for 10 minutes. Subsequently, pyridine $(430 \mathrm{mg})$ and $4(250 \mathrm{mg})$ were added to the reaction mixture. The resulting mixture was reacted at $4{ }^{\circ} \mathrm{C}$ for 20 hours. By the same procedures described in the preparation of $14,4^{\prime \prime}$ - $O$-(cyclohexylthio)acetyltylosin $(100 \mathrm{mg})$ was obtained. ${ }^{1} \mathrm{H}$ NMR, $\delta 1.81$ $\left(3 \mathrm{H}, \mathrm{s}, 12-\mathrm{CH}_{3}\right), 2.54\left(6 \mathrm{H}, \mathrm{s}, \mathrm{N}\left(\mathrm{CH}_{3}\right)_{2}\right), 3.34\left(2 \mathrm{H}, \mathrm{s}, \mathrm{COCH}_{2} \mathrm{~S}-\mathrm{C}_{6} \mathrm{H}_{11}\right), 3.51\left(3 \mathrm{H}, \mathrm{s}, \mathrm{OCH}_{3}\right), 3.63(3 \mathrm{H}, \mathrm{s}$, $\left.\mathrm{OCH}_{3}\right), 4.59\left(1 \mathrm{H}, \mathrm{d}, J_{4^{\prime \prime}, 5^{\prime \prime}}=10 \mathrm{~Hz}, \mathrm{H}-4^{\prime \prime}\right), 5.93\left(1 \mathrm{H}, \mathrm{d}, J_{13,14}=10.5 \mathrm{~Hz}, \mathrm{H}-13\right), 6.28\left(1 \mathrm{H}, \mathrm{d}, J_{10,11}=\right.$ $16 \mathrm{~Hz}, \mathrm{H}-10), 7.36\left(1 \mathrm{H}, \mathrm{d}, J_{10,11}=16 \mathrm{~Hz}, \mathrm{H}-11\right), 9.73(1 \mathrm{H}, \mathrm{s}, \mathrm{CHO}) . \quad \lambda_{\max }^{\mathrm{MeOH}} 283 \mathrm{~nm}\left(\mathrm{E}_{1 \mathrm{~cm}}^{1 \%} 189\right)$.

Anal. Calcd. for $\mathrm{C}_{54} \mathrm{H}_{89} \mathrm{NO}_{18} \mathrm{~S}$ (MW 1,071): C 60.48, $\mathrm{H} 8.36, \mathrm{~N} 1.30$. Found:

C 59.96, H 8.70, N 1.27 .

Tylosin derivatives listed in Table 8 were prepared by treatment of $250 \mathrm{mg}$ of 4 or 7 with the corresponding mixed acid anhydride which was prepared from carboxylic acid by treatment with triethylamine and pivaloyl chloride in methylene chloride under the conditions shown in Table 8.

\section{Acknowledgements}

We wish to thank Prof. S. Mitsuhashi, Department of Microbiology, School of Medicine, Gunma University, Maebashi, Japan, for kindly supplying us the macrolide-resistant clinical isolates of Staphylococcus aureus. We are also indebted to Dr. C. KunIYASu, National Institute of Animal Health, Hokkaido Branch, Sapporo, Japan, for kindly providing us the strains of Mycoplasma gallisepticum and his helpful advice.

\section{References}

1) Okamoto, R.; M. Tsuchiya, H. Nomura, H. Iguchi, K. Kiyoshima, S. Hori, T. Inui, T. Sawa, T. Takeuchi \& H. UMEZAWA: Biological properties of new acyl derivatives of tylosin. J. Antibiotics 33: 1309 1315, 1980

2) Tsuchiya, M.; K. Suzukake, M. Hori, T. Sawa, R. Okamoto, H. Nomura, H. Tsunekawa, T. Inui, T. TAKeUchi \& H. UMEZAWA: Studies on the effects of 3-O-acetyl-4" $O$-isovaleryltylosin against multipledrug resistant strains of Staphylococcus aureus. J. Antibiotics 34: 305 312, 1981

3) Tsuchiya, M.; T. Sawa, T. Takeuchi, H. Umezawa \& R. Okamoto: Binding of 3-O-acetyl-4"'-O-isovaleryltylosin to ribosomes from a macrolide-resistant strain of Staphylococcus aureus. J. Antibiotics 35: $673 \sim 679,1982$

4) Shimauchi, Y.; K.Hori, M. Sakamoto, Y. Mutoh, Y. Fukagawa, S. Hori, T. Ishikura \& J. Lein: Chemical modification of deltamycins. I. 4"'-O-Acyl analogues of deltamycins. J. Antibiotics 33: 284 292, 1980

5) Oкамото, R.; T. Fukumoto, H. Nomura, K. Kiyoshima, K. Nakamura, A. Takamatsu, H. Naganawa, T. TAKeuchi \& H. Umezawa: Physico-chemical properties of new acyl derivatives of tylosin produced by microbial transformation. J. Antibiotics 33: 1300 1308, 1980

6) Nagel, A. A. \& L. A. Vincent: Selective cleavage of the mycinose sugar from the macrolide antibiotic tylosin: a unique glycosidic scission. J. Org. Chem. 44: 2050 2052, 1979

7) Morin, R. B. \& M. Gorman: The partial structure of tylosin, a macrolide antibiotic. Tetrahedron Lett. 1964: $2339 \sim 2345,1964$ 